\title{
Managing Research Libraries in Developing Economy
}

By

\author{
ISKILU B. AHMED
}

\begin{abstract} policy shift to remain relevant in the century.

\section{Introduction}

The role of libraries including public, academic, special, research is central in the process of communicating government produced information to an informed public. Libraries in varying degrees store and make accessible a broad range of information, government policies and publications (sometimes also United Nations, foreign and international). More importantly, they provide indexes, guides and reference services that constitute means of finding specific publications and the information contained in them.
\end{abstract}

Research Libraries are central in the process of communicating and production of information to an informed public. This paper discusses managing research libraries in developing economy. The concepts of special libraries, funding of research libraries, the need for training and retraining of library staff and resources sharing networking were highlighted. The paper recommends that research Institutes need to re-order their priorities through a major

Essentially therefore, the provision of effective and efficient documentation services to provide education, research and development at different level of our economy and social endeavors of various kinds requires that, they be organized within an integrated system which is conceived in relation to and as a part of national plan for economic, political, social and scientific development ${ }^{2}$ Being part of the integral system for positive change in a society. Library and documentation centers makes meaningful, effective and appreciable contribution to national objectives.

Harrod (2001) defined a library as a "collection of books and other library materials kept for reading, study and consultation. These collections (resources) contribute the most potent agent of information storage that are for shaping the future of national problems that concerned mankind as a whole. For optimum utilization of these library collections, they are sieved and repackaged so that every individual user in a way most appropriate and suitable, in a form acceptable and understandable, at the time when needed for individual user to solve specific problem(s) at a specific point in time and situation
Gupata (2008) quoting Saracevic, Tefko and Wood (1981) said information repackaging or information consolidation has been defined as "public knowledge specifically selected, analyzed, evaluated and possibly restructured and repackaged for the purpose of serving some of the immediate decisions, problems and information needs of a defined clientele or social group, who otherwise may not be to effectively and efficiently access and use this knowledge as available in the great amounts of documents or in its original form ...Urquhart (2001) supported this view when he said “... since 1951 research activities throughout the world have increased the volume of recorded scientific and technical information considerably and an important problem now is how to ensure that this information reaches those who can use it. Some of the solution to this challenge requires:

a) That users must know what exists;

b) That users must be able to obtain what they wish to read

The support of such sieved and analyzed information (knowledge) which is international commodity surmounts language barriers and ignores political and religious frontiers for significant serious work for economic, social and scientific development to be accomplished.

\section{Special Libraries}

The spot-light of this write-up is on special libraries. These libraries are usually found in business and industrial establishments, government department, mass communication agencies, universities, hospitals, the military, museums, professional organizations and research institutes. They deal with specialized subjects in depth, serve specialized body of users that are relatively homogenous and employed staff with special knowledge. Their emphasis is on the retrieval of information or data rather than the document. 
Materials assembled by special libraries are the most important source of wealth of their parent organization. They keep staff abreast with up-to-date skills and interest discoveries in their fields of work and profession.

The extent to which the research libraries are able to perform their functions will depend largely on a number of factors which includes adequate information resources, qualified personnel, adequate accommodation and availability of funds. The situation in Nigerian Research Libraries has been that of inability to provide the basic requirements for effective discharge of their duties.

In addition to provision of basic requirements, library staff and researchers need to know and be familiar with the professional literatures and the jargon of the core subject disciplines that makes-up the mandate of their institute. This is important because knowledge of the discipline's KEY TERMS helps in the application of the most appropriate methodologies for search strategies terms i.e. keywords out of context (KWOC), keywords in context (KWIC) etc. the key words and SYNONYMS which represent topics of interest devoid of general terms and ambiguity, helps a great deal in retrieval of information. Equally, short description of the researchers' interest and a set of descriptors or keywords could be developed into staff 'PROFILE' and stored in the computer. This profile will be marched against bibliographical records in the appropriate databases for SDI services to meet the specific of scientists and researchers.

It is pertinent at this juncture to retrospectively consider research libraries throes, vis-à-vis how they had faired, their present state and the surviving strategies to enunciate for their future growth and stability, with a view to postulate conceivable options to ensure their surviving and thriving in a depressed economy.

Retrospectively, in the late 50s and early 60s, Nigeria were only a collection of few relevant books and some periodicals housed in individuals offices of research officers, or in an alternative small room taking charge by a clerk with a designation of a 'librarian'. This trend continued until the establishment of real research libraries namely: Institute of Agricultural Researc (IAR) ABU, Zaria, Nigerian Institute of Oil Palm Research (NIFOR), Benin City, Cocoa Research Institute of Nigeria (CRIN), Ibadan and Forestry Research Institute of Nigeria (FRIN), Ibadan. These libraries offered high standard services in agriculture with emphasis on information dissemination as quickly and efficiently as possible to staff of the organization and to answer specific questions that arose. ${ }^{9}$ With the passage of time and development in information science, libraries have expanded their frontier for information search and dissemination, using modern information technology (IT) gadgets such as computer, CDROM/RAM, internet (information super highway) etc.

Laudable as the objectives of research libraries are, they cannot be achieved without the presence of a vibrant research library (Agolu, 1989). An adequate library is not only the basis of all teaching and study, it is the essential condition of research, without which additions cannot be made to the sum of human knowledge This is also true of a research institute and its library.

\section{Funding}

The present scenario of funding of research institutes and their libraries by federal government and parent ministries or agencies which are the proprietors of the institute, leaves much to be desired. Research institutes funding has continued to dwindle since the mid 1980s along with the downturn in the economic fortunes of Nigeria.

This has resulted in deterioration in the quality of library materials, facilities and services. The implication of this is that, many research libraries have not been able to acquire collections comprehensive enough to meet the needs of their users. The attendant consequences of inadequacy funding is the ability of the libraries to progress beyond the level of application of traditional methods of providing library services not to talk about progressing into the state of vigorous application of sophisticated information technologies (IT) in the libraries. How are research institutes libraries in Nigeria going to cope in the information for their teaming users (scientist/technologist) in the face of inadequate funds, increased demand by their users for up-to-date information and faster means of accessing them. This is a million bugging questions which needs to be redressed. From the foregoing, it is clear that, the bane of our special libraries is saddled on lack of adequate funds. This manifestation is crystal in libraries in older institutions which were painstaking built over the year are now sorry ageing collections, more like museums or achieves of ancient wisdom than living dynamic repositories of man's steady expansion of knowledge and research, which is the hallmark of the library in every society. 
In like manner, libraries in more recent educational and research institutes which started as hopeful educational and research excellence centres are now stultified in their unable to achieve their true potentials and dreams. Practically, everywhere there has been a drastic reduction or absence in journal subscription and acquisition of new books. The result is a growing gap between the current state of knowledge in advanced countries research libraries and what research libraries in Nigeria are able individually and collectively to place at the disposal of their clienteles.

The worrisome trend be-deviling the development and sustenance of effective and functional research libraries in developing countries and Nigeria in particular is not only inhibited by the economic down turned alone. The government and authorities of parent institutions/organizations attitude leaves much to be desired when it come to funding libraries vis-àvis development i.e. acquisition of reading materials and equipment, in spite of the huge sum of money apportion to library development in annual budgets. The library at the end of the day, becomes the least area of priority of most institutes and establishments to be equipped, yet much is expected of it in meeting informational and research needs. The notion's economic theories in recent past i.e. FEM, SAP etc have compounded the problems of research libraries and other tertiary institutions. Libraries are worst hit as they cannot acquire most of the current information materials (professional books, journals, microforms, diskettes, $\mathrm{A} / \mathrm{V}$ equipment) etc because most African countries and indeed Nigeria is vulnerable to currency devaluation as they rely almost entirely on importation to provide educational and research materials. The increase in the number of special libraries orchestrated by the establishment of second and third generation universities and research institutes in the 1980s and 1990s brought a corresponding cost of information package steadily at source. The cost of foreign exchange increased tremendously with economic policies and their attendant consequences and availability became problematic. Libraries in Nigeria are faced with the problem of ivory tower high bills for their Collection Development Programme (CDP). At the same time, their subventions like those of other public funded institutions are declining. The net effect of these economic policies culminate to a new phenomenon called Book Famine or starvation of the mind. This book famine being experienced in every library in Nigeria at varying degrees has led to a general decline in the quality of library services.
The other impact of the decline in library funding in their services, is the way it has frustrated and thwarted plans for automation. It is disheartening to note that most of the research institute libraries are, at various crawling stages of the automation of their resources and services.

The current trend in the developed world in information provision in libraries is through the application of information technologies (IT). Interestingly, it is conversion into CD-ROM library resources of printed nature i.e. reference works encyclopedias. Other reference works, journals, scientific and technical reports, in various disciplines are now held on diskettes etc libraries in these developed countries have now entered the brave new age of information super high way (INTERNET), using communication satellite (C-ROM/RAM) etc where resources of other libraries are linked into vast networks, transcending distances of libraries, states and national peripheral devices and such transmission technique as the optical disc technology have increased the capacities of libraries and information services. All these information technology gadgets are operated electrically to accessed library resources. This brings to mind the erratic power supply of the nation by PHCN called 'RATIONING' or the total absence of power (BLACK-OUT) for hours, days, weeks and even months in our cities and towns thus, crippling vital sectors of the nations' economy.

In spite of all these problems, the library remains unrivaled as the store-house for humanistic scientific and technological knowledge and the repository of our common heritage of human wisdom and civilization. Information therefore has emerged as the important resources for all sound development in this age, and libraries being the leverage for information dissemination, its threshold and relevance in this computer age depends solely on adequate funding to be able to satisfy the demands of the users, vis-à-vis, their information needs. The introspection engendered by the new reality lead to fundamental reordering of the philosophy, goal and practice in research libraries.

\section{Training and Retraining of Library Staff}

Librarianship is a labor intensive service profession, and for the services to be meaningful and result oriented, the services call for skilled and efficient personal. Stuart (1994) quoting Geoffrey Moss in his book The Trainer's Desk Reference said “one of the practical ways of ensuring that we receive the best from our employees, and that they themselves are 
enable to give their best, is to ensure that they are properly trained”.

There is so much involved in adequate staff training and development, and this is another of those fundamental techniques which must be applied at all times. Training and retraining for manpower development is a constant and essential activity for organizations with vision and purposeful objectives to pursue. What then is needed are various post basic specialized training in such widely differing areas of the profession and in multi-media information (its) services and computer based research library network.

\section{The Way Forward For Research Libraries Resources Sharing and Networking: Sharing of library resources means that one library uses the resources of other libraries and vice versa. As such, a group of libraries working together in cooperation for a common purpose of mutual benefit can be termed as "resources sharing system. In effect, the entire resources of all the participating libraries become a common pool with unlimited extension of their boundaries to the extent they have agreed to share their resources.}

The present race between knowledge and book production has made it impossible for any library, however big it may be, to acquire all the printed literature in the world even on the smallest area of the spectrum of knowledge, or to cope with even a fraction of the daily production of literature. According to Sangal 'it is estimated that scientific literature is growing with geometrical progression and is doubling every ten years or so'. From the above, it can be clearly seen that, no library in the world can claim to be sufficient. Therefore, libraries particularly research libraries working together can more effectively contribute to the educational and research programmes.

With a major policy shift by the government, authorities of research institutes in favour or automation and subsequently internet connectivity, proper networking arrangement within each network system to cope with the adoption of such technology in a sharing to cushion the dramatic rise and cost of library resources and services due to the effect of currency deregulation.

The device is imperative as earlier said, no library can be said to be self sufficient no matter how well equipped/stocked it is. Libraries therefore with similar mandates should be encouraged to embark on a deliberate and collaborative venture with a view to fashion out a network system for the purpose of resource sharing. Such economic cost measures pose a challenge for librarians to critically look inwards and effect necessary changes in the structure of their policies services and procedures inherited or developed over time for providing services in order to ensure their suitability and sustenance in a new and competitive information industry.

\section{Conclusion and Recommendations}

The present scenario is that research libraries in Nigeria are backward in the provision of adequate requisite resources for purposeful and meaningful research oriented work for their teaming enthusiastic clienteles (scientists and technologies). This is manifested by the obsolete library equipment i.e. $\mathrm{A} / \mathrm{Vs}$, reference books, poor internet access and journal titles on the shelves which is largely due to funds constrain. The attendant consequence of this is for the scientist to make do with what is available. Thus, creating a big gorge between us and the developed world in terms of new scientific developments and breakthrough. The new information age we already in, is characterized by information revolution resources of libraries generally and application of computers technology in the provision of information services which are still dreams. It is high time for proprietors of research institutes in Nigeria (Federal government, ministries and authorities of the research institutes, need to reorder their priorities through a major policy shift if we shall be relevant in this century. The only requirement to build and maintain the very best library collection involves a deliberate balance between user requirements and library budgets. Therefore, for our resource centers to survive and live up to their expected roles their financial base must be increased. Research libraries should take the queue of universities libraries where $10 \%$ of the total yearly budget is given or designated to the libraries. This is in addition to the library budget. Consequently governments and chief executive of research in institutes should ensure prompt release of funds to the library to enhance their services capacity for effective and meaningful research work. Private organizations i.e. construction, manufacturing, pharmaceutical, financial institutions should be persuaded or compelled by law to contribute certain percentage of their profit turned over for the development of research libraries, as most of them particularly industrial, manufacturing firms, NGOs benefit directly from research results which are vital to their progress. 
Government and authorities of research institutions should evolve deliberate policies of promoting publications of research results in national dailies, local journals and yearly award of research grants. When new grounds are broken (breakthrough), such a person be commended for national award. Private organizations should make their in-house journals free to libraries. Bodies like Committee of Directors of Research Institutes (CODRI) should establish Special Libraries Endowment Funds (SLEF) to be manned by men of proven integrity in the society. In addition, retired and serving distinguished scientists/academicians as friends of particular research institutes based on their inclinations (field of interest or specialty) to assist the libraries by subscribing to a set or sets of particular journals or books set(s) encyclopedias and provide internet access etc as donation for the growth of research in their areas of specialty. Such kind gestures would be acknowledged by benefiting institutions. Reprographic services and acquisition of journal reprints and online access to journals are of high economic importance to special libraries.

\section{References}

Aguolu, C.C. (1989). University of Maiduguri Inaugural Lecture Series No. 45 1988/89 Session. Libraries, Knowledge and National Development p. 28.

Aguolu, C.C. (1989). University of Maiduguri Lecture Series No. 45. 1988 \& 89 Session. Libraries, Knowledge and National Development. P. 38
Fry, B.M. (2007). Government Publications and the Library: Implications for changed Government Publications Review. Vol. 4, No. 2, $111-117$

Gupata, Dadendrak (2008). Information Repackaging: Information Analysis and Consolidation Products. Nigerbiblios. Vol. 13(3) p. 4

Harrod, L.M. (2001). The Librarian's Glossary, Andre Deusth, London p. 38.

James, Stuart (1994). The Manager and the Library: A Review of Some General and Industrial Management Books and their Relevance to Library Management. Library Review. Vol. 43, No. 1, p. 44

Okiy, Rose B. (1998). Nigerian Universities Libraries and the Challenge of Information Provision in the $21^{\text {st }}$ Century. Library Bulletin: Nigerian University Library System. Vol. 3 Nos. 1 \& 2 p. 18

Okiy, Rose B. (1998). Nigerian University Libraries and the Challenge of Information Provision in the $21^{\text {st }}$ Century. library Bulletin: Nigerian University Library System. Vol. 3 Nos. 1 \& 2 p. 19.

Penna, C.V. (1967). The Planning of Library and Documentation Service $2^{\text {nd }}$ Ed. UNESCO, Place de fontenoy.

Sangal, D.G. (1984). Proposals of Resource Sharing Among Libraries in Nigeria. Nigerian Libraries: Journal of the Nigerian Library Association. Vol. $20 \mathrm{p}$.

Urquhart, D.J. (2001). The National Leading Library for Science and Technology. Vol. 13 No. 13 No. 1 p. 14. 